\title{
The Rights ApPROACH TO Local Public Management: experiences from Brazil
}

\author{
Peter Spink \\ Professor of the Department of Administration and \\ Human Resources at EAESP/FGV and Coordinator \\ of the Public Management and Citizenship Program. \\ E-mail: spink@fgvsp.br
}

\section{RESUMO}

O Programa Gestão Pública e Cidadania da Fundação Getulio Vargas, São Paulo, foi criado em 1996 com o apoio da Fundação Ford para identificar e disseminar iniciativas inovadoras na prestação de serviços por governos subnacionais brasileiros com um impacto direto na construção da cidadania. Nos seus primeiros quatro anos, o programa acumula mais de 2.500 experiências diferentes no seu banco de dados. As conclusões iniciais apontam para uma nova abordagem sobre administração pública centrada nos direitos individuais e coletivos e para a importância do envolvimento de outras agências públicas e organizações da sociedade civil no processo de construção de caminhos viáveis ${ }^{1}$.

\section{ABSTRACT}

The Fundação Getulio Vargas, São Paulo, Public Management and Citizenship Program was set up in 1996 with Ford Foundation support to identify and disseminate Brazilian subnational government initiatives in service provision that have a direct effect on citizenship. Already, the program has 2,500 different experiences in its data bank, the results of four annual cycles. The article draws some initial conclusions about the possibilities of a rights-based approach to public management and about the engagement of other agencies and civil society organizations'.

\section{PALAVRAS-CHAVE}

Inovação, governo subnacional, administração pública, cidadania, descentralização.

\section{KEY WORDS}

Innovation, subnational government, public administration, citizenship, decentralization. 


\section{WHAT IS THE PUBLIC MANAGEMENT AND CITIZENSHIP PROGRAM?}

The Public Management and Citizenship Program (Gestão Pública e Cidadania) is an awards and dissemination program for innovations in Brazilian subnational governments, set up in 1996 through the initiative of the Getulio Vargas Foundation in São Paulo (EAESP/FGV) and the Ford Foundation ${ }^{2}$. The Brazilian National Economic and Social Development Bank (BNDES) also provides support. The program's objectives are to encourage Brazilian states, municipalities and the governments of the indigenous peoples to share with others the approaches they are using to solve public issues and respond to community needs, to evaluate and identify the key features of these innovations and to create mechanisms for the widespread dissemination of practical approaches to effective government. The program's approach is resumed in its title; a reference not only to the importance of effective public management but to the impact that this has on the construction of citizenship and the corresponding reduction of social and political exclusion.

A common theme links the Brazilian program to its colleague programs, also founded by the Ford Foundation. Situated in the United States of America, the Philippines and Chile, the programs are coordinated respectively by the John F. Kennedy School of Government at Harvard University, the Asian Institute of Management of Manila, and both the Fundación Nacional para la Superación de la Pobreza and the Centro de Análises de Políticas Públicas at the University of Chile. In all four countries, the starting point is with what is going well in the public sphere; as opposed to the more customary what is going wrong. All have been created at times in which public administration and government were under criticism either through the early neoliberal views of lean government or, later, over questions of performance capacity for service delivery. Whilst it is as scientifically appropriate to focus on what is going wrong as on what seems to be working, there are more clues available in the latter than in the former. It is also more encouraging to investigators and practitioners to know that there are possibilities for action, even though their key dimensions may not yet be clear, and certainly the discussion of action strategies in both community and the classroom is greatly enhanced by the presence of positive outcomes.

The program has as its primary focus: public management activities, projects and programs at the state, interstate, municipal, intermunicipal and indigenous (tribal) levels. These can include partnerships or alliances with organizations within civil society (such as non-governmental organizations, community associations and business firms) but in such cases the coordination has to be clearly in the hands of subnational public sector agencies. The same applies to activities carried out in conjunction with Federal Agencies. All activities, projects and programs have to have at least a year of effective operation and demonstrate clear results of innovation in organization and/or technical strategies to resolve social and community needs in a way that:

- represents a substantive change, qualitatively or quantitatively, in previous practices and strategies within the geographic or thematic area in focus, either through the implantation of a new program or set of activities or the significant improvement of existing activities or programs;

- permits or points to ways in which the experience could be repeated by other and transferred to other regions and jurisdiction;

- broadens and consolidates forms of access and dialogue between society and its public agencies, increasing the quality of political and institutional practice;

- utilizes local resources and/or national and/ or international opportunities within a perspective of responsible development and stimulates, where possible, autochthonous and autonomous practices that can become self-sustaining ${ }^{3}$.

The program uses a broad approach to informing people, jurisdiction, agencies and other organizations of its existence and to attracting innovators to show their work to others. It has to reach all parts of the country, finding its way through often quite complex state level structures, as well as to over 5,500 municipalities and the indigenous peoples, territories and communities. It has to work within areas that are both densely and sparsely populated and get close to those involved in the innovations themselves. It has to deal with possible administrative filters, be able to see past 
shop window innovations to reach those that are happening on the periphery of the public service and, finally, to find those innovative practices that are not necessarily seen as such by their authors. Local innovation often takes place because it has to take place - there is no other option. Problems are tackled because they have to be, using whatever resources are available; otherwise they won't be solved. As a result, those involved may not see what they are doing as an innovation. Innovations can come in all shapes and sizes, from the actions in a major urban industrial center that push forward the boundaries of inter-agency working through careful negotiation and engagement to the inspirational "jeito" of the mayor of a rural municipality trying to get credit to rural smallholdings. The underlying proposition of the program's work is that helping to direct attention to the range of innovation available and building bridges between innovators, will strengthen a wider network of social authors and of collective authorship, reinforcing the build up of competence and increasing the stock of knowledge available.

At the start of the annual cycle, the program brochure is mailed to nearly twenty-five thousand addresses and complemented by a specific word of mouth campaign using gatekeepers, professional meetings, work groups and events that deal specifically with thematic areas. Contact is also made directly to jurisdictions whose work has been reported by the press, discussed in conferences, disseminated by NGOs or published in the academic and technical journals. At the beginning, there were many suspicions about political neutrality, regional and topic biases; here the action of program staff and Technical Committee members who establish contacts over the phone with initial inquirers and encourage them to go ahead is very important in building up credibility. Credibility is also helped by the fact that both the foundations involved are highly respected for their treatment of data and information and for their broad concern with strengthening democracy.

One of the first acts of the program was to set up a Technical Committee, or steering committee, which forms an outreach network of organizations active in the public sector for dissemination and evaluation and provides regional and thematic orientation to the program as a whole. Active also in certain phases of evaluation, Technical Committee members ${ }^{4}$ also join the research efforts of the program, carrying out studies of thematic interest. Currently the following institutions form part of this committee: the Postgraduate Administration Programs of the Federal Universities of Bahia, Paraíba and Rio Grande do Sul; the Brazilian School of Public Administration (EBAP-FGV/RJ);

\section{The program's objectives are to encourage states, municipalities and the governments of the indigenous peoples to share the approaches they are using to solve public issues and respond to community needs.}

the School of Government of the State of Minas Gerais (João Pinheiro Foundation); the Nucleus for Studies of the Amazon, Federal University of Pará; the Polis Institute São Paulo; the Postgraduate Program in Environmental Science and the Nucleus for the Study of Violence, both of the University of São Paulo; the Center for the Study of Public Policy (CEPP), Rio de Janeiro; the Center for Actions in Gender, Citizenship and Development (AGENDE), Brasília; the Federation of Agencies for Social and Educational Assistance (FASE), Rio de Janeiro; and the Council for the Articulation of Brazilian Indigenous Peoples and Organizations (CAPOIB), Manaus.

The program's annual cycle begins during the months of December, January and February with emphasis on outreach, dissemination and identification of potential innovations. Applications take place usually in April by filling in a simple four-page form with descriptive questions and a self-evaluation of results and contribution. This is followed by the selection of 100 projects as that year's semifinalists. For this, members of the Technical Committee, FGV teaching staff, postgraduate students and NGO colleagues work in small groups over two days. Each entrant is discussed 
and rated separately by two groups and a final discussion by all evaluators of the selected cases also takes place. The semifinalists send fuller details of their activities by replying to a set of questions formulated by the project team and Technical Committee. At the next stage, normally in June, some thirty specialists drawn from universities, technical centers and NGOs with considerable practical experience in different fields of public administration and social action, helped by other colleagues, choose thirty programs and projects as pre-finalists. For this, each project is placed in two different clusters; one by area and the other mixed. This way each is seen both in its specific technical context and within the general context of innovative action. Again each is evaluated by a different set of panelists and there is a general all-in discussion at the end.

In July, site visits are made to each of the thirty pre-finalists by independent advisors, many of whom are either NGO staff, staff from research centers or advanced postgraduate students. A preparatory training week is held during which the overall program is discussed, evaluation methods suggested and a lot of debate about innovation takes place. In 1999, a small group of UK and USA postgraduates ${ }^{5}$ also joined in and accompanied Brazilian colleagues in the fieldwork. Following the site visits, the Technical Committee plus invited colleagues study the field reports and choose the twenty finalists.

The finalists are invited to an all-day meeting in São Paulo or Rio de Janeiro, where they make oral presentations of their projects and reply to questions formulated by a "jury" composed of leading figures from civil society, who have also studied the site reports. All are invited to be present at the oral presentations to hear about the programs and many opportunities are also provided during the day for individual finalists to meet and talk. All the finalists are already prize winners and will receive their certificates but, in keeping with the climate of friendly competition and in a very culturally appropriate way, at the end of the day, the jury deliberates privately and declares five of the twenty as the most outstanding. The presentation of certificates is followed by a cocktail, with opportunities to talk to the press and generally be together. The awards are small in value $(\mathrm{R} \$ 3,000.00$ for each finalist and $\mathrm{R} \$ 10,000.00$ for each of those chosen as outstanding) and have to be used in activities relating to the winner project, such as publications, equipment, visits and seminars. What is most striking and generally commented about "finals day" is the spirit of comradeship that builds up between people from the most different of jurisdictions, from the north to the south of the country and across the political spectrum.

The evaluation and choice of the semifinalists, finalists and outstanding programs is the tip of the iceberg of the program's activities and care is taken to ensure that each phase is seen as representing the community of innovators as a whole. Thus, the five chosen as outstanding represent the twenty, who in turn represent the hundred who represent all those who are taking part that year and who, in their turn, represent all that have taken part in the four years of the program. All the valid entrants received ${ }^{6}$ are registered in a database that is permanently open to the public along with other materials (such as videos, documents and brochures) that are sent by the different subnational governments. Lists are produced of the different programs for distribution, and the database is made available in both paper and electronic form. The site visit reports are published in book form and members and colleagues from the Technical Committee also generate research and descriptive documents which are made available through the program's technical note series ${ }^{7}$. The basic rule in relation to information and contacts is that reflected in the program's title: public management and citizenship. Knowledge, ideas and experiences must be open and available to all and each and everyone must judge what they regard as important for themselves. The program staff, when asked about possible strategies, will not identify any one project as being the best or the ideal way. On the contrary, they will point to various possibilities from different years and suggest that as well as reading the descriptions available, the person concerned should make contact with those involved. As a result of this approach to information as public property, the database is in constant use by journalists, students, political parties, mayors and government advisors to learn about possibilities and identify contacts for discussion.

\section{WHAT IS INNOVATION?}

The most frequently asked question in the program's short history is what it means by 
innovation? What is innovation in subnational government and how can breakthroughs and ruptures in public management and citizenship be recognized? What makes a method novel and how much do previous practices have to alter before they can be considered innovative? The program in fact offers very few elements for an answer; at each stage the selection process is oriented to the basic criteria of the program, to its title and to the four points made at the beginning of this article. However it also, through much discussion with the Technical Committee, has developed a further baseline, that of self-identity. If those who submit programs, projects and activities consider that what they are doing is in some way innovative for them, in their settings, the program will accept that, try to understand this and include the description in all its publications. The posture is therefore inclusive; concern is with increasing and strengthening the wider community of those who are seeking to intervene at the intersection of public management and citizenship.

From this basis the evaluators in the different phases are asked to enter into honest dialogue one with another in the search for those programs, projects and activities which for them seem to express the overall aim. Curiously, opening up the process in this way - as opposed to tying it down with criteria - has served to help the evaluation groups through tricky moments and has created a communal basis that unites the evaluators in their tasks. Indeed, recognizing the critical discussion that has taken place over science and technology in recent years, it is more than clear that there can be no final definition of what an innovation is nor can there be abstract divisors of why one quality should be rated higher than another. Dialogue, as communicative action in the Habermasian sense (Habermas, 1984), represents a community approach to the constructive comprehension of the emerging present; a process that is often heated but that will always go on until consensus has been reached.

Linked to the theme of innovation as an open ended and socio-historical process is the question of the subtle but crucial distinction between the "innovation" stance and that of "best practices". Here the view of the program collective is that the "best practices" approach, however sincerely formulated, will lead to normative judgments of actions that "should" be followed because they are "right". The "innovations approach", on the contrary, is seen much more as a challenge to debate and to links and dialogue between people and agencies who are trying in different ways to change public practices. The former ends up by becoming what could be called science from without, a black box "know-what" approach to action and development that falls easily into the trap of imitation. The latter is science from within, the dramatic and dilemma ridden search for know-how and know-why that is rooted in its circumstances.

\section{Helping to direct attention to the range of innovation available and building bridges between innovators, will strengthen a wider network of social authors and of collective authorship.}

In a series of internal seminars, this question has been discussed through, amongst other angles, that of the relation between innovation and knowledge. Is there a difference, in terms of the development of knowledge, between possible lines of approach that stimulate reflection and those that set out to identify a specific or "best" practice that should be followed? Within the second, favored by Multilateral Organizations such as Habitat, UNAIDS and the World Bank, concern is with identifying the best in a specific field, so that this may serve as a model to be obligatory or preferably followed by others. The result, as it could only be, is an extensive list of criteria that should be applied in effectively distinguishing what is "best" from what "isn't". Implicit here is a theory about adequate administrative action, conceived a priori. For example, the instructions for submitting "best practices" to Habitat comprise nine pages in English and the descriptive requirements cover more than thirty-six questions that have to be taken into consideration. UNAIDS' proposal for "best practices" also reflects the classic program evaluation format with almost forty questions in six areas: effectiveness, impact; relevance; efficiency; sustainability; rigor and ethics; and replicability. Whilst certainly well intentioned, 
the risk is in creating subtle processes of exclusion whereby those who come forward are those that dominate the technical and official jargon of the area. Many innovators and social actors do not work from these perspectives and for them the fragmentation of their experience into multiple categories can be alienating.

A second difficulty comes from the explicit suggestion that best practices are in fact "models" to be followed, albeit with a small degree of local adaptation. To use examples as inputs for a discussion about possibilities of action is not in itself problematic, providing that this is part of the identification and codification of practical and derived knowledge about knowhow, know-what and know-why. However, when the examples are presented as "best", there is an immediate risk of them being seen as norms with a result that their usefulness is restricted to a role of replication. This becomes even worse when, in the subtlety of the International Aid arena, certain practices are associated with the availability of funds and other resources (a process that goes back many years). The result is that knowledge is reduced to that which is precoded and the idea of emergent, implicit or tact knowledge ("embedded", to use the expression of Clifford Geertz (1983)) is dismissed.

Many innovators, as was commented earlier, do not see what they are doing as innovative; for them it is a question of solving problems and using that most ubiquitous of local knowledge codes "common sense". Yet as Geertz has commented: "it is an inherent characteristic of common-sense thought precisely to deny this [that it is a relatively organized body of considered thought] and to affirm that its tenets are immediate deliverances of experience, not deliberate reflections upon it." Common sense is recognized, called upon, questioned, developed and even taught and it can vary dramatically. It is embedded; matters are intrinsic, inherent, the way things go, it is seen as accessible to those sound of mind and practical of consciousness.

Embedded knowledge is a socio-technical rather than social phenomena, in that it is rooted in products, artifacts, traces, instruments and sequences of action. Building up adequate descriptions in such settings requires an open and field grounded stance in which the emphasis is on listening; very different to the closed question procedure or pre-established parameters adopted by many of the "best practice" approaches.
In the last fifteen years, there has been a rapid growth, in a number of fields, of evaluation techniques and forms of effectiveness audit. Programs to judge quality, the ISO standards used in industrial partnerships and international supply, the business world thirst for excellence and benchmarks of competence have spilled over into the public sector. Those who arrive at the LASA congress through Miami International Airport can testify to the certificates of competence displayed by its Customs Department. Indices are being fixed in health, education and general public service, therefore why not "best practices"?

Without doubt the development of performance measurement, as one amongst many ways of placing in public debate what is happening, is a positive and helpful step for establishing dialogue. But when "what is" is transformed into "what should be", dialogue rapidly gives way to patterning and patterning quickly becomes a hostage of hegemonic interests. Suddenly, the inability to explain an experience within a logical framework or the absence of indicators becomes characterized as a lack of competence. Within the over exaggeration of preferred patterns, presentation skills can assume the place of substance.

Unfortunately it is not possible to draw a simple boundary between open and historically constituted processes searching for applicable knowledge and the potentially tyrannical closed process by which "right" is attributed. Both are products of modernity, of reflexivity and of the idea of improvement and change. Both are produced and reproduced within the conflicts between different basis of knowledge and attempts at dominance over the socially imagined; between the lifeworld and steering mechanisms within the politics of reality. The negative consequences of the "audit" culture, in which description becomes recipe, and the positive concerns with transparency and dialogue are two sides of the same figure.

Being constantly open about the program's process and about how the judgments have been made has generated a climate in which, without doubt, project managers are upset that their activities have not "made it through" but are hopefully understanding and comprehensive about the result. Care is taken at each step in the selection process to avoid suggestions of rejection of those who did not 
make it through to the next phase. All know that their experiences will be part of the database and that a printed version will be produced for widespread distribution and that they will receive a copy. Each entrant receives a certificate of participation, as well as a copy of the database for that year and great care is taken in dissemination to draw attention to the variety of experiences that have been registered.

\section{THE RIGHTS APPROACH TO PUBLIC ADMINISTRATION}

Whilst the program holds open its position on innovation, it is also prepared to recognize that its title "public management and citizenship" does reflects a concern with service provision and public sector management that is in many ways different from that suggested by the State Reform agenda of Multi-lateral Agencies, or of some local interpretations of the New Public Administration. Here, despite various arguments to the contrary, it has to be recognized that the debate around the reform of the State in Latin America is not just a technical one ${ }^{8}$. The consequences of what has been termed neoliberalism within the framework of structural adjustment and State Reform ${ }^{9}$ have led many to be naturally suspicious of the way in which reform arguments can be mobilized.

Especially important are those concerns that focus on the price being paid for greater flexibility and increased outsourcing of public actions; for example, in reduced transparency (Aucoin, 1990 $)^{10}$. Privatization may have its arguments in favor, but there are many questions emerging out of experiences elsewhere to show that the path to regulation is by no means an easy one $^{11}$. Results-oriented management, it has been argued, can create a closed box within which the flow of information about work in progress - the everyday procedural monitoring of action - is held, thus turning it inaccessible to elected officials and citizens for whom efficiency in relation to pre-defined performance standards are deemed sufficient. "Voice", within the Hirschman model (Hirschman, 1970), requires the possibility of presence; following the execution of budgets and assuming watchdog roles over procedures is as much a part of active democracy as is being satisfied with results.

Scholars in the USA, where the "reinventing government" movement has been strong, have already raised the specter of what has been called "faux democracy", a shadowy version of the ideal (Box et al., 1999), a result of a very thin relationship between citizen and state, signified by occasional ballots punctuating periods in which economic and managerial effectiveness is assumed to be sufficient. A similar concern has been raised about the danger of the subtle substitution or equalization of citizenship with service user or consumer. As a result, there has been a clear counter movement to locate public administration more clearly within the space of democracy, using notions of active citizenship, public interest and governance ${ }^{12}$.

\section{What is innovation in subnational government and how can breakthroughs and ruptures in public management and citizenship be recognized?}

If results-based or managerial approaches to public services are creating concern in established democracies where a large number of institutional checks and balances are in place, then the situation worsens in settings where there is a real need to develop and strengthen citizenship. Here, so the argument runs, the results-based service model because results take time to emerge and generate consequences and impact - is simply not sufficient to stimulate the kind of dialogue that in turn helps to build citizenship.

Social development and the dramatic indicators of inequality in human development in Latin America have been on the agenda of regional organizations in Latin America for a number of years. Bernardo Kliksberg (1994, 1999), for example, has been a constant voice in drawing attention to the State's role in relation to social issues and poverty. Concern with effective public policy and with the impact on the citizen is a feature of the Latin American Council for Administrative Development's new policy document (Centro Latinoamericano de Administración para el Desarrollo (CLAD), 1998) and many Latin American Governments 
have been signatories to international agreements of recent years in the areas of human rights, gender, the environment and other matters. This is bringing the social focus of public administration and social policy management skills firmly onto the reform agenda.

The social situation is alarming throughout the region, with World Bank data showing some 200 million people at or below the 1 US\$ per capita per day level of minimum survival. In Brazil, similar estimates place this at between $40 \%$ and $50 \%$ of the population. Poverty, however, cannot be reduced to income and employment, for no amount of individual income can provide many of the basic services that are necessary for community life (such as health, education, justice, security, solid waste management, and water). Equally, the presence of a social minimum of services and income is no guarantee of an end to social exclusion and inequality ${ }^{13}$; itself Brazil's major challenge. To move beyond this into what a number of us ${ }^{14}$ have termed the "rights"-based approach to public administration, it is necessary to closely examine the practices and priorities of the service relationship with specific groups. It becomes vital to consider ways in which empowerment is stimulated and above all turn public service organizations outwards towards citizens and increase their sensitivity to the many small elements of service provision that create subtle and not so subtle barriers to the poor, to women, to indigenous peoples and afro-descendants. Concern, as O'Donnel (1998) has put it, is with the truncated nature of democracy that emerges in societies in which there is on the one hand a reasonable presence of universal legal rights (elections, political parties, social organizations, press, etc.) but, on the other, widespread poverty and inequality within which citizens are de facto deprived of the possibility of exercising autonomy and action. The discussion of the relationship between State and Civil Society is, at the mid-range level of public actions, a question of social engagement, of representation and of the way in which public administration is able to break with many of those practices which had left it very much at the service of private interests, of patrimonialism and of the monopolies of power ${ }^{15}$.

Advocates of the rights approach are concerned about the democratic process and, in this respect, the approach is essentially non- partisan in nature, gathering support from many sectors that are concerned with the lack of effective democracy within the region. It is political only to the extent that its proponents are against those who would restrict rights and access or who would wish to retain the State's services for private interests. It places its emphasis not only on results but also on the nature of the relationship that is built up with citizens; it essentially argues in favor of turning public administration sensitive and more focused by working from the outside in. Managers play their role, but it is the capacity to judge impact and consequences and to evaluate the micro-processes of service delivery that is placed in the foreground.

The assumption that it is better to have more services, even if these are less transparent, more managerial and less procedurally accountable, has been a subtle yet constant feature in many development programs. The result has often been that those better placed to take advantage of increased service provision, or even of its introduction, are those who have done so. Gaps have widened, not merely as a result of macroeconomic turbulence and strategies adopted for fiscal stability, but also through the skewed redistribution of opportunity and access to services and resources. Any strategy that is based on merely expanding services or providing more of the same will inevitably run the risk of reproducing existing patterns of exclusion. Moving the focus to the construction of citizenship places the change and improvement in such existing patterns at the top of the development agenda. It asks service providers, administrators, those involved in support activities and in the supervision of these activities, to look at their day to day tasks in a different way. Services are judged to be efficient and effective not because they are more rapid, or cheaper, or produce more action, but because they generate tangible, acceptable and clear consequences for the conditions and practice of citizenship, both for those receiving and providing services and for the wider community within which these actions take part.

These are seen as aspects of governance ${ }^{16}$, the relatively stable and enduring dynamics of control and communication that societies develop and adjust over time to provide themselves with security, prosperity, coherence, order and continuity. Formed through the clash of interests, the public arena is a space where 
differences can be recognized and where underlying conflicts are maintained under negotiated limits. Developing democracy is a constant process that includes - but goes beyond - the time span of any particular government's period in office. The "rights approach" offers a citizen centered perspective on State reform, arguing for inclusion, the reduction of inequalities and the strengthening of democratic governance as urgent priorities for the focus and evaluation of the results of government action.

Seen as an action-research project, for the act of identifying and disseminating is a process of data gathering, theory building and open debate, the "public management and citizenship program" based itself on the proposition that the rights approach to public management and service provision is not only possible, but is also understood and shared by a significant number of those facing the dilemmas of every day. Consequently, as the first brochures went out in the mail in 1996, all those involved stopped to think. Would there be jurisdictions, organizations and agency workers for whom the idea of public management and citizenship would make sense? Would the program help them position themselves in relation to what they were doing? Would they be interested in dialogue ${ }^{17}$

\section{AN OVERVIEW OF THE FIRST FOUR YEARS}

Perhaps the most significant and the most overlooked result of these first four years is the most obvious one; the questions posed in the brochure did indeed seem to make sense to a sizable proportion of subnational jurisdictions and continue to do so (Table 1$)^{18}$. So far, the program has received some 2,500 different entrants from a variety of different subnational jurisdictions, led by different political parties, many of which have over five years of effective implantation. There is indeed a lot going on and

\begin{tabular}{|c|c|c|c|c|c|c|}
\hline Jurisdiction & 1996 & 1997 & 1998 & 1999 & Total & Total \% \\
\hline State & 134 & 122 & 224 & 157 & 637 & 26.1 \\
\hline Municipal(1) $^{(1)}$ & 488 & 174 & 400 & 721 & 1,783 & 72.9 \\
\hline Indigenous & 7 & 1 & 7 & 10 & 25 & 1.0 \\
\hline Total & 629 & 297 & 631 & 888 & 2,445 & 100.0 \\
\hline
\end{tabular}

(1)Includes a small number of intermunicipal consortiums. the framework of administration and citizenship is clearly a valid one: project descriptions submitted are generally clear, well thought out and extremely honest in terms of perspectives and possibilities.

In the first year of the program (1996), 629 valid initial entries were received from state, municipal and indigenous peoples' organizations. This was the final year of the municipal government cycle and some 120 municipalities submitted experiences, often with many projects together, as well as many different state agencies. Overall, counting state, municipal and indigenous programs, only the states of Tocantins, Sergipe and Rio Grande do Norte were not present, but would be so the following year. In the second year, it was expected that there would be a reduction in numbers, both due to it being the first quarter of the first year of the new municipal term of office and also to jurisdictions doing their own preselection of possible candidates. The impact in the press to the first year of the program had been considerable for a new event and, despite the municipal change around, there were still 297 valid entrants from 95 municipalities, sixty-six state level agencies and one from the indigenous peoples own organizations. In 1998, the trend continued to rise with 631 programs from state, municipal and indigenous peoples' agencies representing some 208 different jurisdictions as well as agencies from all but two states (Alagoas and Rio Grande do Norte), and in 1999 with 888 valid entries representing over 284 jurisdictions and agencies from all but one state (Alagoas).

Whilst entries have been received from all over the country, there is a strong presence of the southeast and south with a growing presence of the north and northeast (Table 2).

\begin{tabular}{|c|c|c|c|c|c|}
\hline Region & 1996 & 1997 & 1998 & 1999 & Total \\
\hline North & 2.7 & 2.7 & 4.1 & 4.3 & 3.6 \\
\hline North-east & 11.1 & 20.5 & 9.5 & 13.1 & 12.6 \\
\hline South-east & 61.1 & 40.4 & 51.4 & 51.0 & 52.4 \\
\hline South & 21.3 & 20.9 & 26.6 & 29.6 & 25.6 \\
\hline Center-west & 3.8 & 15.5 & 8.4 & 2.0 & 5.8 \\
\hline & (100) & (100) & (100) & (100) & (100) \\
\hline
\end{tabular}

Examining only the municipal initiatives and, therefore, not considering the location of state 
level initiatives, it is interesting to note that whilst the municipalities in the 50,000-500,000 population group have a higher presence in the program than they do relatively in the country (43\% of municipal entries versus $10 \%$ of all municipalities in the country), a substantial number of entrants do come from the small municipalities of less than 20,000 inhabitants, a group normally seen as weak in resources and competence. Table 3 shows the distribution of municipalities that submitted programs in 1998 and 1999 in relation to their population and contrasts this with the 1996 IBGE data on the size distribution of municipalities.

Table 3 - Population profile of municipalities submitting entries in 1998 and 1999

\begin{tabular}{|c|c|c|c|c|}
\hline $\begin{array}{l}\text { Population } \\
\text { (in } 1,000 \text { ) }\end{array}$ & 1998 & 1999 & Total & $\begin{array}{l}\text { IBGE } \\
\text { Brazil }\end{array}$ \\
\hline$>20$ & 35 (24\%) & 69 (30\%) & $104(28 \%)$ & $70 \%$ \\
\hline $20-50$ & $23(16 \%)$ & $46(20 \%)$ & $69(18 \%)$ & $19 \%$ \\
\hline $50-100$ & $28(19 \%)$ & $35(15 \%)$ & $63(17 \%)$ & $6 \%$ \\
\hline $100-200$ & $18(12 \%)$ & $28(12 \%)$ & $46(12 \%)$ & \\
\hline $200-500$ & $23(16 \%)$ & $31(14 \%)$ & $54(14 \%)$ & $4 \%$ \\
\hline $500-1,000$ & $6(4 \%)$ & $7(3 \%)$ & $13(3 \%)$ & $0.5 \%$ \\
\hline $1,000-5,000$ & $8(5 \%)$ & $6(3 \%)$ & $14(4 \%)$ & \multirow[t]{2}{*}{$0.5 \%$} \\
\hline $5,000<$ & $2(1 \%)$ & $2(1 \%)$ & $4(1 \%)$ & \\
\hline No data & $3(2 \%)$ & $4(2 \%)$ & $7(2 \%)$ & \\
\hline
\end{tabular}

All entrants are asked to self classify their program, project or activity within 7 categories of governmental action, shown in Table 4, most of which are also subdivided. Thus, public services include topics such as: education, health, housing, transport, culture, leisure, public safety and policing. Citizenship and human rights is subdivided by focus: children and adolescents, age, black citizens, women, people with impairments, consumers and minorities. Administration and government covers forms of planning, inter-agency coordination, public buildings, budgeting, information systems, popular participation in government as well as staff development and forms of control. Economic and social development covers science, technology, industry, agriculture, fishing, agrarian reform, skill training and employment creation. Infrastructure and environment covers such topics as water, sanitation, energy, telecommunications, urbanism in general, environmental controls, solid waste and pollution.

What is interesting to note is that whilst nearly all are working at the interface of public management and citizenship, citizenship is not chosen as the major focus for their activities. Rather, they report themselves within the public management categories that are normally used to describe their work, suggesting that there is indeed an emerging new framework for public administration, at least at subnational level. A rightsbased approach is not being seen as a separate category of administrative action or yet another division of governmental action, but as a way of thinking about administrative action as a whole.

Table 5 shows the subareas that have attracted the higher number of entrants over the four years. Education, children and adolescents, health and social welfare are items that head the list, all of which are areas in which there has been a growth of subnational competence either because of the dramas of demand, or through the process of decentralization and municipalization that has been taking place in Brazil and which will be commented on later. A further stimulus may well

Table 4 - Percentage distribution of entrants according to general area

\begin{tabular}{|c|c|c|c|c|}
\hline Area & 1996 & 1997 & 1998 & 1999 \\
\hline Public services & 44.5 & 48.5 & 40.9 & 45.1 \\
\hline Citizenship and human rights & 16.4 & 17.2 & 27.1 & 25.7 \\
\hline Administration and government & 17.2 & 9.4 & 12.4 & 10.1 \\
\hline Economic and social development & 10.2 & 14.1 & 10.8 & 9.6 \\
\hline Infrastructure/environment & 10.3 & 10.4 & 8.1 & 8.7 \\
\hline Judiciary & 1.1 & 0.3 & 0.5 & 0.5 \\
\hline Legislative & 0.3 & - & 0.3 & 0.3 \\
\hline & (100) & (100) & (100) & (100) \\
\hline
\end{tabular}


be with the various consultative councils at state and municipal level that were set up as a result of the 1988 constitution, especially in areas such as of education, health, children and adolescents, social work and employment.

Programs, projects and activities cover a vast range of different actions and contain many different aspects and approaches that, to resume some of the comments made by observers, may range from the ingenious, the so obvious but why didn't any body think about it, the absolutely brilliant or awesome, through to the one percent inspiration and ninety nine percent transpiration; and the lets try to do it right for once and not keep reinventing the wheel. What, however, marks them out is the constant involvement of electors, communities and citizens in discussing what should be done and the collective, if not indeed civic, pride that they display in talking about what has been achieved. So as to avoid singling out one or the other experience as representative, an impossible task, the eighty finalist programs from the first four years have been briefly described in the appendix and provide a very good cross-section of the groundbreaking that is taking place subnationally in the country. In relation to the indigenous programs, the bringing together within the same space and with the same criteria of the different institutional components of Brazil's subnational arena has made at least a minor contribution to widening respect and transferring knowledge in a variety of directions. Here practical responses to questions such as crop and game management, demarcation of land, the recuperation of traditions and the development of health and education services in a culturally compatible form have been amongst the topics brought forward.

Seen overall the four years are reflecting a tendency towards the construction of a rightsbased approach to subnational government in Brazil; more efficient and effective, and open to dialogue between society and its public agencies. The results obtained so far are permitting a number of analyses and colleagues, including members of the Technical Committee and a growing body of postgraduate students, are generating some useful reflections ${ }^{19}$. In addition to the many sector-based analyses or specific studies of cases and approaches, two broad lines of discussion are emerging. The first referring to the content of policies and the second to new forms of managing, deciding and providing public services (Farah, 1999).

Within the first, changes are being noted in the way that services are being considered, for example, a much greater emphasis on preventive and community based health rather than curative medicine, and also in developing replies to new challenges such as school evasion. The question of social exclusion is very much to the forefront - as can be expected given the nature of the challenge that the program posed by asking about public management and citizenship. There are clear attempts amongst the innovators to broaden citizenship through taking services and access

Table 5 - The percentage distribution of the most present subareas for each of the four years 1996-1999

\begin{tabular}{|c|c|c|c|c|c|}
\hline Subarea & 1996 & 1997 & 1998 & 1999 & Total \\
\hline Education & 16 & 20 & 12 & 14 & 15 \\
\hline Children and adolescents & 8 & 9 & 16 & 16 & 13 \\
\hline Health & 13 & 15 & 12 & 13 & 13 \\
\hline Social work & 3 & 2 & 4 & 10 & 5 \\
\hline Culture & 6 & 6 & 4 & 4 & 5 \\
\hline Planning and management & 6 & 4 & 4 & 4 & 4 \\
\hline Job training and employment & 3 & 4 & 5 & 5 & 4 \\
\hline Senior citizens & 2 & 2 & 3 & 4 & 3 \\
\hline Leisure & - & 1 & 3 & 3 & 2 \\
\hline Minorities & 2 & 1 & 2 & 2 & 2 \\
\hline Other areas & 41 & 36 & 35 & 25 & 34 \\
\hline
\end{tabular}


to groups that in the past have been left out. Thus the black community, women, aged and people with impairments are being focused with specific programs and activities as are also children and adolescents in what are termed risk settings. Here the important feature has been a break with previous approaches that have been based on the mere provision of social assistance and the adoption of strategies that have a clear impact on the notion of citizenship. Policing is gradually emerging as an area for action as are activities linked to the legislative and other institutions that are key to strengthening democracy. Environment was a concern of militant groups in the 1980's and it has been encouraging to see how many well-thought-out public environmental management programs are now underway and to see also the way in which urban concerns with solid waste are being rethought in relation to job creation. Also, general administration and financial management are beginning to be valued as crucial aspects of a jurisdiction's relationship to its citizens. Planning methods, participatory budgeting, public information systems and simplified procedures for documents and other public sector requirements are becoming more present. Finally, in the general area of social policy, there is also a significant move towards more longer term subnational interventions in the area of employment and income generation in which subnational governments are assuming - with support from other actors - a role that goes beyond that of temporary relief.

These examples of public management activities, projects and programs are pointing to a trend which is very different to that which used to characterize Brazil up to the early 1980s. Then, as my colleague Marta Farah (1997) has commented, State intervention in the social area was typically: centralized at the federal level; institutionally fragmented; exclusive rather than inclusive; narrow in action, sector by sector; very much conditioned by private interests; conducted according to the patronage power of specific groups; vertical and bureaucratic; averse to civil society participation and control. These elements may still remain, but they are being increasingly pushed aside by another way of thinking about public administration.

Comments on new forms of managing, deciding and providing public services have already been emerging from a number of different observations and case studies on municipal and state governments (Lesbaupin, 1996; Nogueira, 1992; Figueiredo and Lamounier, 1996; Tendler, 1997). What the data from the public management and citizenship program can provide is both a confirmation of this tendency which has spread across party lines and also comment on what appears to be a clear inter-organizational approach amongst innovators to the way of going about service provision.

Firstly, it is easy to underestimate the importance of what appear on the surface to be very simple measures and provisions, especially in areas that in many established democratic countries are seen as rights. Providing information to citizens is taking place in many ways, from electronic websites, through to kiosks and even - in small municipalities - to painting the budget on the outside wall of the village school. Simplifying procedures for documents and the provision of what have been called "one stop shops" are changing the patterns of expectation between citizens and the state and providing street level public servants with a very different, community centered working environment. Services are being targeted to their focus populations with an increased involvement of citizens in service supervision, breaking with the previous pattern of generic social policy action provided in a standard way in all settings. Brazil's participatory budget programs at subnational level have already been recognized in international forums and their constant presence in the program, both as specific entrants and as background features of other innovations, has shown how they bring about a greater engagement in the joint management of local actions. Finally, mention should be made of new forms of coordination that are being tried at subnational level, in which adjacent municipalities are gathering together to create local agencies for water management, health and hospital provision, economic development and joint agricultural green belts. Different from the top-down approach common in decentralization or regionalization programs, these represent local attempts to create what are initially voluntary forums in which resources and concerns can be mobilized. Intermunicipal consortiums take time and political patience to set up, but they are difficult to stop once they have been able to gather momentum. 
Relations between organizations and agencies in the provision of services provide another outlook on the way that management is changing. In the classic model of both service administration and project implementation, activities are seen as being coordinated in a hierarchical fashion within the managerial boundaries of a specific agency. Thus, education takes care of education, the water boards the water supply and the health service, health. When these are focused at a specific target - for example, urban poverty - each tends to have their own definition and often their own captive clients. This single agency, unitary management model on which most management teaching is based, is very different from what has emerged from looking more closely at the different programs and projects submitted over these four years. What appears to be happening in the field is much more a process of involving other organizations in different patterns of alliances, links or even partnerships for service provision. Table 6 shows the breakdown for each year of the broad patterns of linkage in service provision with other public sector agencies from the same or different levels of government, with civil society organizations of different kinds and with both non-governmental and other government agencies ${ }^{20}$.

As can be seen, the model of the single agency carrying out its own activities is no longer the dominant approach, present in only $20 \%$ of all entrants during the four years. On the contrary, programs are taking place with the support of other agencies, or with civil society organizations and more often than not with both at the same time. In some $46 \%$ of cases, these involve 1 or 2 other organizations, in $24 \%$ of cases, 3 or 4 other organizations, in $15 \%, 5$ or 6 other organizations, in $9 \%$ of cases, between 7 and 9 other organizations and, in $6 \%, 10$ or more other organizations are involved. The range is from small scale and more intimate interorganizational linkage up to, in a few cases, large-scale organizational collectives with an amazing variety of different social actors. In a special project that was set up on the theme of poverty and social exclusion, program staff has been able to take a closer look at the way some of these links and alliances are formed ${ }^{21}$. What is striking is that they are rarely conceived and planned at the outset as complex pieces of institutional engineering; rather the linkages tend to happen over time as opportunities and demands arise, being slowly built up along with the level of inter-organizational competence and inter-organizational respect.

At the governmental level, these links may be from the same or different levels of jurisdiction and, at non-governmental level, many of the organizations involved are the more traditional civic and community based organizations, representing different and at times conflicting groups within civil society - rather than the newer NGO or third sector associations. These are present, but often in the larger municipalities where professional groups and associations have been created on thematic concerns. In most places and cases, it is the former more traditional civic organizations that express some form of community responsibility and concern that will characterize the partnerships between public and non-public organizations; a phenomena that lends support to the discussion of community competence as described by Putnam (1993). An example of the cross-section of non-public organizations is given in Table 7.

In a specific study carried out on some 274 municipal projects from the 1996 cycle $^{22}$, it was possible through telephone interviews and faxed questionnaires to take a look at some of the

Table 6 - Broad patterns of linkage amongst entrants 1996-1999

\begin{tabular}{|c|c|c|c|c|c|}
\hline $\begin{array}{l}\text { Partnership with other } \\
\text { government agency }\end{array}$ & $\begin{array}{l}\text { Partnership with civil } \\
\text { society organizations }\end{array}$ & 1996 & 1997 & 1998 & 1999 \\
\hline No & No & 19 & 24 & 19 & 20 \\
\hline Yes & No & 27 & 18 & 17 & 19 \\
\hline No & Yes & 16 & 13 & 13 & 13 \\
\hline Yes & Yes & 38 & 45 & 51 & 47 \\
\hline
\end{tabular}


different reasons given for the linkages to public and non-public organizations. As can be seen from the summary in Table 8 , the priorities are quite different, reflecting a broad resource utilization approach that mixes different areas of competence, skill, opportunity and formal resource provision.

In the same study of the 1996 entrants, it was also possible to take a look at a constant feature in the imagined social and political world of government change: discontinuity. This was the year of municipal elections in Brazil and 1997 would mark the beginning of the new governments at local level. An early indicator that discontinuity was not as widespread as imagined came from the continued presence of municipal entries in the 1997 cycle; with the one year rule they would have had to have been initiated in the previous government. In broadening this to some 274 projects which were contacted a year after the elections, it was found that again a majority of programs $(88 \%)$ had continued, independently of political party. The reasons given were usually pragmatic: the program, project or activity was working and had been accepted as such by all parties during elections. However, it was also the case that many of these also had forms of linkage with other organizations. The numbers involved are too skewed because of the overall tendency to continuity to permit anything but an observation on this score, but of those that did continue $78 \%$ had links, partnerships or alliances of some kind whilst the corresponding figure for those that did not continue was $35 \%$.

Another study ${ }^{23}$, using the entry forms for 1997, 1998 and 1999, shows that of a total of 1,798 state and municipal level programs, projects and activities for which clear data was available, some 946 (52\%) had been initiated in the term of the current government (that which was in office at the time of inscription); 606 (34\%) had been initiated by the previous government and, therefore, had been continued, and $246(14 \%)$ had begun even before that. Strikingly, the sub-distributions for state and

\section{Table 7 - Examples of non-public organizations involved in joint service provision}

\begin{tabular}{|l|l|l|}
\hline Nursery and baby minding groups & Ecological movements & Residents associations \\
\hline Neighborhood committees & Rural area committees & Centers for human rights \\
\hline Women's defense councils & Church agencies & Children's defense councils \\
\hline Local churches & Health users groups & Trades unions (urban and rural) \\
\hline Co-operatives & Local bus companies & Sports clubs \\
\hline Local commerce & Insurance companies & Banks \\
\hline Universities & Research centres & Community councils \\
\hline Indigenous councils & Indigenous action groups & Lawyers associations \\
\hline Mothers clubs and groups & Lions and Rotary & School PTA \\
\hline Social movements & Chambers of commerce & Farm owners associations \\
\hline Rural producers groups & Voluntary bodies & Church philanthropic groups \\
\hline Service and advocacy NGOs & International - Caritas & Multilateral - Unicef, UNDP \\
\hline
\end{tabular}

\section{Table 8 - Reasons for linkage with public and non-public organizations}

\begin{tabular}{|l|l|}
\hline Other governmental organization and agencies & Non-governmental and civil society organizations \\
\hline Financial $(30 \%)$ & Operational $(38 \%)$ \\
\hline Technical and logistics $(25 \%)$ & Co-implementation $(32 \%)$ \\
\hline Co-implementation $(23 \%)$ & Co-management $(24 \%)$ \\
\hline Operational $(18 \%)$ & Technical and logistics $(22 \%)$ \\
\hline Co-management $(8 \%)$ & Financial $(19 \%)$ \\
\hline
\end{tabular}


municipal governments are very similar. Given a natural tendency by any jurisdiction to put forward programs that have been introduced in the government of the day and therefore any bias will be against the past and in favor of the present, the results both certainly support the argument that continuity is growing and probably are a sub-estimate of what is happening on the ground. That is, at least within this significant and substantial minority of jurisdictions that seem to have embarked on a different approach to public management and service provision.

\section{Is this decentralization?}

Of the many themes that circulate around the topic of the development of subnational governments in third-world regions, the most ubiquitous is perhaps that of decentralization. In the early post-war period leading up to the early 1960 's, decentralization was placed on the high moral ground along with democracy and economic development, serving as a lever for the former and a guarantee of the latter (Smith, 1988; Spink, 1993). At the same time, forming a space for myth and narrative, it was also recognized that decentralization was a difficult process. Problems of skills, traditionalist or patrimonialist styles and cultures, local elites and personalist leaders, lack of fiscal competence or structure and corruption were amongst the many elements that were identified. Decentralization was seen as de-centralization, that is the delegation or transference of authority, power and or services from the center, which could or could not also include the corresponding structures of democratic representation (Smith, 1985).

By the early 1980's, decentralization was beginning to acquire a further layer of meaning as part of the growing debate on economic reform and the fairly widespread adoption of structural adjustment models (Schuurman, 1997). National Governments were seen as top heavy and needing to be "downsized" or "rolled back" - to use two of the many expressions that circulated through the public administration of the period. The argument was that public services should be decentralized either to the market (outwards) or to the local level (downwards) as a way of guaranteeing a better "customer-oriented" service. In many Latin American countries, given the lack of an effective local government framework (Nickson, 1995), the answer were the various parallel Social and Emergency Investment Funds organizations and structures, which were in effect to assume most, if not all, of social policy.

\section{Many innovators do not} see what they are doing as innovative; for them it is a question of solving problems and using "common sense".

Finally, at least for the moment, decentralization has acquired a further layer of meaning; in relation to its role in strengthening the broader social fabric. Events in Eastern Europe (Keane, 1988), the earlier recognition of the role played by non-governmental organizations $^{24}$ and the importance attached to participation in rural and urban development planning experiences ${ }^{25}$, brought decentralization back to the social arena as a challenge to the new orthodoxy of privatization. Decentralization was seen as either a strategy for strengthening civil society or, inversely, the strengthening of civil society was itself be seen as a requirement for decentralization; thus providing a new and updated version of the decentralization equals democracy equals economic development triad. As these various meanings were woven through the existing fabric of ideas, apparently changing yet curiously maintaining the broad assumptions of development, the economic or market arena would also be brought in to play through the growing emphasis on the role of philanthropic and private (business and commercial) organizations as part of the societal capacity for social policy action.

However, despite the various changes and additions of meaning, the basic elements of the decentralization supposition have remained. That is of a process that is seen as requiring action by the center to transfer outwards from the state or downwards towards the local, that is thwarted either by the resistance of the former or the incompetence of the latter. Whilst the tension present appears to suggest conflict, in fact, the 
two halves of the argument fit together, forming a cohesive framework for the wider assumption about the validity of the nation-state and the role of the central government as the crucial part of its governance regime. In terms of Foucaultian governmentality (Burchell, Gordon and Miller, 1991), de-centralization is a constant reaffirmation of the center.

Brazil, until fairly recently, has occupied a relatively unique position in Latin America, through having a long established tradition of municipalities conceived as having jurisdiction over clear and contiguous territorial areas. Despite a lack of financial and political autonomy, this was somewhat different to other Latin American models in which it was the centrally appointed regional or departmental administration that cared for the local and in which the town was a reference in itself and not to the surrounding rural areas. This pattern is rapidly changing as different Latin America governments move to re-configure the local arena, but Brazil still remains an important source of case material from which to seek more longer term conclusions.

Traditionally both research and conventional wisdom saw the municipality in Brazil as important within regional power structures and alliances, yet operationally weak in service provision and dominated by the Federal Government, which held part of the purse strings, and the State Government, which held the other part. The common narrative saw the municipality as dependent financially, technically and politically, without resources and skills to attend local demands. Those funds that were made available were obtained through clientelist relations with state and federal political figures, in exchange for guaranteeing both the supply of electoral funds and the votes of electors. In short, an internally consistent and compatible version of the "why you should decentralize but why it is difficult" story line.

The 1988 Constitution created, amongst others, a different basis for municipal autonomy through guaranteeing the principles of the formal transfers of funds and taxes between federal, state and municipal jurisdictions. Whilst major taxes remain at federal and state levels, the return to the municipality of a proportion of taxes on economic activity has proved an important complement to other sources of funds. Whilst the municipalities own tax income has remained at three and a half percent of the total, available funds have risen from nine and a half percent to sixteen percent of the total available with some $28 \%$ at state level.

Amongst the many other constitutional changes in 1988 was the introduction of previously mentioned supervisory councils in a number of social areas, but this took place amongst the growing economic problems of the decade and to patterns of inflation and overall financial crisis that would not change until the "Real" plan was introduced in the final period of the Franco government (1993-1994). The Cardoso government has continued to maintain macro-economic rigor and the reduction of Federal Government spending has thrown a greater responsibility to the states and municipalities. The result has certainly not been a planned process. Rather, as Celina Souza (1996) has suggested, it has been more unplanned, somewhat uncoordinated and without any real change in expenditure patterns. Any use of the word decentralization tends to be applied as a description after events have taken place, rather than to part of any prior planning.

A similar pattern of findings emerges from the various programs, projects and activities submitted to the Public Management and Citizenship Program. Even in the few areas where there might be a government policy on decentralization, the approaches taken have been the most varied and certainly not at all consistent with the "policy from the center" "action at the local" type of distinction. The same applies when examining the presence of other organizations, a feature of the "decentralization outside government" approach. As has been seen in Tables 6, 7 and 8, the variety involved and the reasons used are hardly consistent with the simple "civil society - NGOs - new service providers" version of the decentralization narrative. The word NGO may indeed have permeated the local space and many will use it, but they will do so to refer to a wide variety of class and neighborhood associations, clubs and groups that includes traditional church organizations, business peoples clubs and commercial bodies, universities, foundations, local charities, political parties and thematic support groups as well as the more visible advocacy and development NGOs and new philanthropic agencies. 
A further element comes from the view that has emerged from evaluators that the ideas behind the programs, projects and activities have largely originated in the practitioners themselves, the technical management and staff, with some presence of popular pressure. Equally, it was the technical areas that were largely responsible for implantation, counting on support from both the political leadership and other organizations. Ideas may come from other parts of the country, other countries in Latin America and throughout the world, but they usually move around through the networks that the technical and professional staff themselves maintain, including contacts with technical organizations, NGOs and international alliances. Often they form part of "invisible libraries" that are being gradually built up through both inductive and deductive means, uniting the empirical and the theoretical with a fairly large dose of pragmatism. Mayors, governors, secretaries and political leaders are also demonstrating their skills in program management. On the downside, actions still tend to emerge from the executive and agency areas of local government and not from the legislative. In the follow-up study of the 1996 cases, the legislative was mentioned in thirty-eight percent of cases as having approved the program, but it was only in a very few that they had played an active role. However, media approval especially of local radio and newspapers - was mentioned by over seventy-five percent of the respondents as an important element in measuring impact and in gaining positive sanction for the activity.

It would appear that consistently yet slowly (for participation can be more like consultation when looked at more closely ${ }^{26}$ ), citizenship and the rights approach to public administration is finding its way into the subnational government agenda and, more importantly, onto the electoral platform. Self-financed attempts at solving problems, the use of multi-organizational partnerships, bi-partisan support for social and technical programs, and the emergence of clear areas of professional competence that utilize but are not dependent on federal and state support are suggesting new processes at subnational governmental levels in which staff and public agency practitioners are exercising both leadership and action skills. Judith Tendler's (1997) study of subnational government in the state of Ceará, for example, pointed independently to a simple but very real conclusion - give capable people the space to work and the encouragement to seek solutions and they will usually find a way through.

The many examples that the Public Management and Citizenship program has registered and is disseminating are neither the exception nor the norm. Rather, they represent elements of what is perhaps a competing narrative within the complexity of the

\section{A "rights"-based approach to public administration is concerned with ways in which empowerment is stimulated and to turn public service organizations outwards towards citizens.}

development debate. They are not taking place because of decentralization or through any clear mechanisms of transference. They are happening because whilst the same square meter of public ground is at the same time municipal, state and federal, it is the first or the second depending on the region, that is ultimately held responsible. But the question still needs to be asked, is this merely representative of haphazard or post hoc decentralization, or are more subtle institutional transformations taking place?

Perhaps it becomes necessary to ask if the hollowed-out State of the global economy and the commented deconstruction of the Westphalian model (McGrew, 1997) are being replaced in a dense and simultaneously multidirectional manner, not by a new de-centralized State (that would only serve to confirm the center), but by a multifocal institutional framework in which a different local establishes itself as a mid-range set of partnerships and arrangements? Certainly Bauman's (1998) conflictual and marginalizing splitting off of the global and the local cannot be simply resolved by the harmonious decentralization from one to the other; a sequential or staircase model of 
planned decentralized actions. Could the various examples that are emerging represent what could be described as a re-centering of different alliances within a civic structure of an expanded public sphere; that which concerns people in communities, their responsibilities to one another and also their conflicts (Habermas, 1989, 1996)? The rights approach to public administration is in itself a re-centering from the general to the specific and, to some extent, from the mandate to the electorate. Problems of governmentality remain, but they are emerging within a scenario in which both continuous and discontinuous transformations are present.
De-centralization as a narrative may, with hindsight, be shown to have only served to confirm the center; to have created a tension between levels of government that have sustained, whilst appearing to change, the Nation State. The processes that are beginning to emerge within Brazil and other Latin American countries may, in time, point to some very different directions for the materialization of democracy and for new patterns of governance. Within this process, innovation programs such as the Public Management and Citizenship Program may well prove, along with the many other observatories being set up, to offer both an important vantage point and some useful contributions.

\section{REFERENCES}

AUCOIN, P. Administrative reform in public management: paradigms, principles, paradoxes and pendulums. Governance, v. 3, n. 2, p. 115-137, 1990.

BAUMAN, Z. Globalization: the human consequences. Cambridge : Polity Press, 1998

BEBBINGTON, A. New states, new NGOs? Crisis and transition among rural development NGOs in the Andean region. World Development, v. 25, n. 11, p. 1755-1765, 1997.

BOTERO, D. I. R. Relaciones Estado-sociedad civil en el campo social. Una reflexión desde el caso colombiano. Reforma y Democracia, v. 7, p. 127-154, 1997.

BOX, R. C. et al. New public management and faux democracy. Omaha : University of Nebraska, 1999. Mimeo.

BRESSER PEREIRA, L. C., SPINK, P. K. (Orgs.). Reforming the state: managerial public administration in Latin America. Boulder : Lynne Rienner, 1999.

BURCHELL, G., GORDON, C., MILLER, P. The Foucault effect: studies in governmentality. Chicago : University of Chicago Press, 1991.

CAMAROTTI, I., SPINK, P. K. Estratégias locais para redução da pobreza: construindo a cidadania. São Paulo : Programa Gestão Pública e Cidadania, 1999. Documento Síntese.

CAMAROTTI, I., SPINK, P. K. Parcerias e pobreza: soluções locais na construção de relacões socioeconômicas. Rio de Janeiro : Editora da Fundação Getulio Vargas, 2000.

CARROLL, T. F. Intermediary NGOs: the supporting link in grassroots development. West Hartford, CT : Kumarian Press, 1992

CENTRO LATINOAMERICANO DE ADMINISTRACIÓN PARA EL DESARROLLO (CLAD). Una nueva gestión pública para América Latina. Caracas : CLAD, 1998.

CLARKE, T., PITELIS, C. (Eds.). The political economy of privatization. London : Routledge, 1993.
EVANS, T. (Org.). La transformacion neoliberal del sector público. Managua : Latino Editores, 1995.

FARAH, M. F. S. Gestão pública e cidadania: iniciativas inovadoras na administração subnacional no Brasil. Revista de Administração Pública, v. 31, n. 4, p. 126156, 1997

FARAH, M. F. S. Parcerias, novos arranjos institucionais e políticas locais. In: FUNDAÇÃO PREFEITO FARIA LIMA - CEPAM (Org.). 0 município no século XXI: cenários e perspectivas. São Paulo: CEPAM, 1999

FIGUEIREDO, R., LAMOUNIER, B. (Orgs.). As cidades que dão certo. São Paulo : M.H.Communicação, 1996.

FRIEDMANN, J. Empowerment: the politics of alternative development. Oxford : Blackwell, 1992.

GEERTZ, C. Local knowledge. New York: Basic Books, 1983.

GRAU, N. C. Repensando lo público através de la sociedad: nuevas formas de gestión pública y representación social. Caracas : Editorial Nueva Sociedad/CLAD, 1997.

HABERMAS, J. The theory of communicative action. Cambridge, MA : MIT Press, 1984. v. I \& II.

HABERMAS, J. The structural transformation of the public sphere. Cambridge, MA : MIT Press, 1989 .

HABERMAS, J. Between facts and norms. Cambridge, MA : MIT Press, 1996

HIRSCHMAN, A. 0. Exit, voice and loyalty. Cambridge, MA : Harvard University Press, 1970.

HOPENHAYN, M. Recomposición de actores en programas sociales: consideraciones desde la experiencia latinoamericana. Reforma y Democracia, v. 7, p. $63-82,1997$

KEANE, J. Democracy and civil society. London : Verso, 1988.
KLIKSBERG, B. The "necessary state": a strategic agenda for discussion. International Review of Administrative Sciences, v. 60, p. 183-196, 1994.

KLIKSBERG, B. Desigualdade y desarrollo en América Latina : el debate postergado. Reforma y Democracia v. 14, p. $7-58,1999$.

LEMARESQUIER, T. Beyond infant feeding: the case for another relationship between NGOs and the United Nations System. Development Dialogue, v. 1, p. 120 125, 1980.

LESBAUPIN, I. (Org.). Prefeituras do povo e para o povo. São Paulo : Edições Loyola, 1996.

MARCH, J. G. OLSEN, J. P. Democratic governance. New York : The Free Press, 1995

McGREW, A. (Org.). The transformation of democracy. Cambridge : Polity Press/Open University Press, 1997.

NICKSON, R. A. Local government in Latin America. Boulder : Lynne Rienner, 1995.

NOGUEIRA, H. (Org). Experiências inovadoras de gestão municipal. São Paulo : Polis, 1992.

O'DONNEL, G. Poliarquias e a (in)efetividade da lei na América Latina. Novos Estudos CEBRAPE, v. 51, p. 37 61, 1998.

PINHO, J. A. G. Reforma do aparelho do Estado : limites do gerencialismo frente ao patrimonialismo. Organizações e Sociedade v. 5, n. 12, p. 59-80, 1998.

PUTNAM, R. D. Making democracy work: civic traditions in modern Italy. Princeton : Princeton University Press, 1993

ROSENAU, J. N. Governance in the twenty-first century. Global Governance, v. 1, n. 1, p. 13-43, 1995

SCHUURMAN, F. J. The decentralization discourse: post-fordist paradigm or neo-liberal cul-de-sac? European Journal of Development Research, v. 9 , n. 1, p. 150-166, 1997 
SEN, A. Inequality re-examined. Cambridge, MA : Harvard University Press, 1992.

SWEDISH INTERNATIONAL DEVELOPMENT COOPERATION AGENCY (SIDA). Helping governments work: a rights approach to public administration and the development and improvement of the capacity of public services. Stockholm : Division for Democratic Governance, 1998. Preliminary Document.

SMILLIE, I., HELMICH, H. Non governmental organizations and governments: stakeholders for development. Paris : OECD, 1993.
SMITH, B. C. Decentralization: the territorial dimension of the state. London: George Allen and Unwin, 1985

SMITH, B. C. Bureaucracy and political power. Brighton : Wheatsheaf Books, 1988.

SMITH, S. R., LIPSKY, M. Nonprofits for hire : the welfare state in the age of contracting. Cambridge, MA : Harvard University Press, 1993.

SOUZA, C. Redemocratization and decentralization in Brazil: the strength of the member states. Development and Change, v. 27, n. 3, p. 529-555, 1996.
SPINK, P. K. Decentralização: luto ou luta. In: FISCHER,T. (Ed.). Poder local: governo e cidadania. Rio de Janeiro : Fundação Getulio Vargas, 1993.

TENDLER, J. Good governance in the tropics. Baltimore : Johns Hopkins Press, 1997.

TENORIO, F. Gestão pública e cidadania: metodologias participativas em ação. Revista de Administração Pública, v. 31, n. 4, p. 101-125, 1997.

WAMSLEY, G. L., WOLF, J. E. Refounding democratic public administration: modern paradoxes, postmodern challenges. Thousand Oaks: Sage Publications, 1996

NOTES

Paper presented at XXII International Congress of LASA, Latin American Studies Association, Miami, Florida, March $16-18^{\text {th }}, 2000$.

1. The Public Management and Citizenship Program is essentially a collective endeavour and many thanks are due to my co-director, Marta Ferreira Santos Farah, Ilka Camarotti, coordinator of the special project on Poverty, and to the program staff which include many FGV postgraduates, which are very capably led by Viviane Novell Ails: Fabian Paschal Cinches, Fernando Martinez de Oliver, Hello Batiste Barbs, Juliana Maria Paris Spink, Luis Mario Fujiwara, Maria Beaters de Araújo Asperti, Marlei de Oliveira, Nelson Luiz Nouvel Alessio, Patricia Laczynski, Ricardo Ernesto Vasquez Beltrão.

2. Ford Foundation members Bradford Smith, Elizabeth Leeds, Michael Lipsky and Nigel Brooke have been a constant source of encouragement and ideas as have many other members of the Ford Governance and Civil Society network. Since 1997, they have been joined by Beatriz Azeredo and Marta Prochnik from the BNDES.

3. Taken from the program regulations. A full description of the program, application forms, regulations and all material generated can be found on its website (http://inovando.fgvsp.br) or by post at Escola de Administração de Empresas de São Paulo, Fundação Getulio Vargas, Av. 9 de Julho, 2029, Bela Vista, São Paulo (SP), CEP 01313-902, Brazil. Telephone: 55-11-281-7904 - fax: 55-11-287-5095

- e-mail: inovando@fgvsp.br.

4. By listed order of institution: José Carlos Gomes de Pinho, Humberto Marques Filho, Luis Roque Klering, Fernando Guilherme Tenorio, Laura da Veiga, Edna Ramos de Castro, Silvio Caccia Bava, Pedro Jacobi,
Nancy Cardia, Thereza Lobo, Marlene Libardoni, Grazia di Grazia and Jorge Terena. A key role in the earlier years was played by Ailton Krenak of the Nucleus for Indigenous Culture.

5. Centre of Latin American Studies (Cambridge and the Brazil Center), University of Texas (Austin).

6. At least 1 year of effective operation and coordinated by a subnational public sector agency or indigenous peoples own government.

7. A full list of all publications and technical notes is available on the web page, most of which can be downloaded and other ordered directly from the program office.

8. See the various papers brought together in Bresser Pereira and Spink (1999).

9. See Evans (1995) for a critical discussion in relation to Central America.

10. For a specific discussion of the non-profit sector, see Smith and Lipsky (1993)

11. See the various countries in the studies organized by Clarke and Pitelis (1993).

12. See Refounding Democratic Public Administration organized by Wamsley and Wolf (1996).

13. Here the works of Friedmann (1992) and Sen (1992) are of extreme importance.

14. See the preliminary work of the Division fo Democratic Governance, Swedish Internationa Development Cooperation Agency (SIDA) (1998).
15. See recent discussions in Latin America by Botero (1997), Grau (1997), Hopenhayn (1997) and Pinho (1998).

16. This is the broad definition provided by Rosenau (1995), see also March and Olsen (1995).

17. The anxiety grew to alarming levels as the deadline for entries approached - as indeed it continues to do year after year. But, true to Brazilian tradition, all the entrants arrived at the last minute, flooding out the FGV mail system and blocking its switchboard.

18. Special thanks to Ricardo Ernesto Vasquez Beltrão, Patrícia Laczynski, Roberta Clemente, Rosane Keppke, Fernanda Martinez de Oliveira and José Luis Abreu Dutra for the various tables in this section.

19. A reminder that all material generated within the program is available for downloading from the program's website or can be obtained in printed versions from the program office.

20. Data analyzed by Fernanda Martinez de Oliveira and José Luiz Abreu Dutra.

21. For a fuller description, see Camarotti and Spink (1999, 2000).

22. Research undertaken with Roberta Clemente and Rosane Keppke.

23. Carried out by Ricardo Beltrão.

24. For example, Carroll (1992), Lemaresquier (1980), Smillie and Helmich (1993).

25. For a good discussion on Latin America, see Bebbington (1997)

26. See the study by Tenorio (1997) on the 1996 entrants.

Appendix: the twenty finalists programs 1996-1999

1996

Programa de Saúde Global: Mobile health and documentation program for the rural communities of the municipality of Joaíma in the state of Minas Gerais.

Pólo Agroflorestal: Municipal agricultural reform program for the resettlement of rubber workers in Rio Branco, Acre.
Fundo de Desenvolvimento Agropecuário: Municipa development fund in the small town of Tupandi, Rio Grande do Sul, which led to a return of younger members of the community and a growth in agricultural development.

Universalização do Ensino: Program of free education and elimination of illiteracy in the town of Icapui, Ceará, with community involvement in the decision-making process.
Projeto Jaburu: Project developed by the indigenous Xavante community of Pimentel Barbosa, in Mato Grosso, for ecological preservation of species vital for traditional hunting practices.

Central de Abastecimento de Campinas: Integrated program of food supply and central market organization, in the municipality of Campinas, São Paulo. 
Programa de Geração de Emprego e Renda: Program for the generation of jobs and income in Quixadá Ceará, offering technical courses and training programs to low-income families.

Programa Nutrir: Nutritional program of the town of Apucarana, Paraná, seeking to reduce infant malnutrition through various lines of action.

Coleta de Sementes Nativas do Serrado e das Matas: Preservation of the native woodland and shrubs around the water catchment areas of the city of Franca, São Paulo, through community seed identification, collection and transplantation.

Programa Lixo que não é Lixo: Program of waste recycling and food distribution in the city of Curitiba, Paraná, that encourages ecological awareness.

Porto Alegre Mais - Cidade Constituinte: Citizen Planning Program in Porto Alegre, Rio Grande do Sul, developed over successive years and already a model for other towns.
Comissão Permanente de Investigação e Fiscalização das Condições de Trabalho: Permanent commission for investigating and monitoring work conditions in the state of Mato Grosso do Sul, involving some 300 state, federal, non-governmental and community agencies.

Modelo de Gestão dos Resíduos Sólidos: Waste management program in Belo Horizonte, Minas Gerais, integrating activities of waste treatment with improvements in the working conditions of the municipal street cleaners and popular education.

Projeto Meninas de Santos: Special program for adolescent prostitutes and street girls in the city of Santos, São Paulo, working with self-esteem as the central theme of workshops, leisure activities and job training programs.

Programa Bolsa Familiar para a Educação/BolsaEscola: Family education and grant scheme in Brasília, in the Federal District, guaranteeing a minimum wage monthly to low-income families with school-age children upon regular classroom attendance.
Programa Municipal de Informação ao Consumidor: Consumer information program in Juiz de Fora, Minas Gerais, seeking to help access to lower-cost food products through data banks, and price lists published in local newspapers.

Projeto Casa Rosa Mulher: Health care, counseling an educational activities provided for sex professionals, adolescent girls and women in situations of domestic violence or personal risk, in Rio Branco, Acre.

Programa Médico da Família: Rural family doctor program in Londrina, Paraná, providing health services within the rural communities.

Projeto São Pedro: Desenvolvimento Urbano Integrado e Preservação do Manguezal: Integrated program aimed at preserving swamp vegetation and ecology while working with the urbanization of favelas in the city of Vitória, Espírito Santo. Lines of action include habitation, infrastructure, health and education.

Projeto Conviver: Integration of children and elderly people through mutual education in the tiny town of Duque Bacelar, Maranhão.
Programa Miguilim: Integrated network of actions for children and adolescents at social risk, in Belo Horizonte, Minas Gerais, working with areas such as lodging, food, education, health and family counseling.

Criança Fora da Rua, Dentro da Escola: Family support program in the city of Fortaleza, Ceará, seeking to keep children in school and off the streets by offering educational grants for low-income families with school-age children.

Projeto Auto-Estima das Crianças Negras: State initiative by the Maranhão government working with black children and adolescents from rura communities to strengthen their sense of cultural and ethnic identity.

Procon-Mirim: Consumer education program in Brasilia, in the Federal District, seeking to teach children their rights as citizens under the Consumer Defense Law.

Universidade do Professor: Teacher's training activities run by the state of Paraná for public school staff, offering specialization courses, motivational seminars, and workshops for updating and administrating curricular activities.

Projeto de Interiorização da Fundação Carlos Gomes: Musical education program of the state of Pará for children and adolescents in small communities encouraging new values, and creating opportunities for professional musical training.
Programa de Capacitação de Agentes Comunitários: Community health program in the rural town of Alcantil, Paraíba, training community-based agents in basic health-care services and disease prevention methods.

Programa Médico de Família: Family doctor program in the city of Niterói, Rio de Janeiro, using small mobile health teams to reach areas with little access to health resources, and administrated both by local government and community associations.

Centro de Referência de Atendimento ao Idoso: Specialized health and social care for the elderly population of Vitória, Espírito Santo.

Instituição Comunitária de Crédito "Portosol”: Credit program in Porto Alegre, Rio Grande do Sul, aimed at small and micro enterprises excluded from the formal financial market.

Programa de Produção Associada com Garantia de Renda Mínima: Municipal development program from Jundiaí, São Paulo, creating alternatives for families and individuals in situations of extreme poverty.

PROVE-Programa de Verticalização da Pequena Produção Rural: Program within Brasília, in the Federal District, supporting creation of small agricultural industries in rural communities.

Programa de Auto-Demarcação Madijá: Territorial control and inspection program in the indigenous reservation of the Madijá, in Acre. Technicians train the Madijá in simplified topographic techniques, so work can be carried out and supervised locally.
Consórcio Intermunicipal de Recuperação da Bacia Hidrográfica do Ribeirão Lajeado: Program for the integrated management of the Ribeirão Lajeado basin, in the state of São Paulo, working towards maintaining and recuperating the local ecosystem.

Projeto Mutirão Reflorestamento: Forestry project from the city of Rio de Janeiro planting bare hills to reduce landslide risk with help from the surrounding communities.

Ação Integrada nos Bolsões de Pobreza Urbana: Low cost housing project in Ipatinga, Minas Gerais, promoting community involvement both in construction work an in parallel initiatives in areas such as health and education.

Vila Rural: State initiative in Paraná creating rural housing projects for migrant farm workers to stimulate the establishment of rural communities and help reduce migration to urban centers.

Abastecer/Comboio do Trabalhador: Food produce pric regulation system in Belo Horizonte, Minas Gerais, helping stimulate small producers as well as offering the population good quality products at low prices.

Programa Terra Solidária: Rural reform program in Iguaraçu, Paraná, where property owners concede unused land for migrant workers to cultivate, trained and assisted by government agents.

Assistência Mãe Canguru: Health program in Recife Pernambuco, for premature babies where - once past critical state - infants exchange hospital incubators for their mother's breast. Skin to skin contact speeds growth and strength gain, and reduces infection risks, as well as reducing operational costs.
Manejo Integrado da Bacia Hidrográfica do Rio Almada: Program of the Almada River basin area in Bahia, encouraging sustainable development by implanting industrial initiatives while promoting ecological awareness.
Projeto Plano de Trabalho da Promotoria de Defesa Comunitária: State initiative of Goiás providing legal advice for the low-income population, defending citizenship rights and encouraging civil rights awareness within these communities.
Programa de Desenvolvimento Auto-Sustentável na Pré-Amazônia Maranhense: Promoting the selfsustainable development of the agricultural sector of the pre-Amazonian region of the state of Maranhão. 
Núcleo Intersindical de Conciliação Trabalhista: Juridical body made up from a number of workers unions and other class organizations seeking to create a permanent space for the negotiation of answers to work-place conflicts in Patrocínio, Minas Gerais.

República Bem-Viver: Collective housing project in Santos, São Paulo, for the physically independent, low-income, elderly population, as an alternative solution to institutionalization and preserving dignity while avoiding depression and loneliness.

Reforma Agrária Solidária: Agricultural restructuring program helping landless agricultural workers and farmers in the state of Ceará negotiate land acquisition loans and grants for the development of production and social infrastructure.

Recuperação da Agricultura Tradicional Indígena e de seus Valores Culturais: Re-introduction into the Kapey indigenous community, in the state of Tocantins, of native seeds and plants once used for food and lost in the transition to the "white man's" agricultural process. The process also recuperates forgotten cultural traditions.

Convênio Creches Comunitárias: Involving the lowincome population of Porto Alegre, Rio Grande do Sul, in the decision process about the use of public resources for infant education, and the creation of qualified educational spaces for infants of 0-6 years.
Projeto Parteiras Tradicionais do Amapá: Program in the state of Amapá, for the training and supervision of traditional mid-wives, improving the condition of homebirths and diminishing death-rates, while attaining official recognition for the profession.

Programa Mala do Livro-Bibliotecas Domiciliares: Program from Brasília, in the Federal District, seeking to introduce the concept of libraries to the low-income populace and promote social aggregation by establishing community libraries in volunteer homes.

Projeto Cidadão: Documentation program in the state of Acre bringing services to economically and socially destitute communities for the provision of birth and marriage certificates, identity cards, work permits and other necessary documents at no cost

Projeto Saúde Mental: Initiative from Belo Horizonte Minas Gerais, which substitutes the psychiatric hospita as therapeutic resource for the mentally ill, providing treatment without social exclusion and re-claiming the citizenship rights of the mentally disabled.

Combatendo a Evasão Escolar: Program in Santa Maria, Rio Grande do Sul, encouraging class attendance within the municipal school network by creating awareness through meetings with educators, parents and children, and home visits.

Casa do Caminho-Albergue que Abriga Mulheres Vítimas de Violência: Assistencial program for women victims of violence and their children in Fortaleza, Ceará offering social care, health and psychological support and job training, amongst others
Programa de Fomento a Pequenos Negócios/Setor Informal: State program for the generation of jobs and income in Espírito Santo through loans for setting up small business enterprises, encouraging the formation of groups and cooperatives.

Educação na Prisão: Initiative from Brasília, in the Federal District, preparing convicts for re-insertion into social and family life, and the job market, in order to avoid recurring crime.

Projeto Casa de Zabelê: Providing care for girls who are victims of abuse, violence and sexual exploitation, the program from Teresina, Piauí, focuses on the girlchild as developing woman and citizen.

Programa Autogestão da Limpeza Pública: Program from Timóteo, Minas Gerais, decentralizing the public cleaning services by setting up cooperatives with the local community, and hiring staff from the community itself.

Câmara do Grande ABC: Intermunicipal consortium of the $A B C$ region of São Paulo formulating regional strategic planning through cooperation of the city halls and mayors.

Trienal de Medicina Tradicional do Povo Baniwa e Kuripako: Attempting to preserve the knowledge of popular medicine of the Baniwa and Kuripako Indian tribes in Amazonas, as well as discourage the rural exodus of the indigenous peoples.
Programa Construindo uma Educação Escolar Indígena: Co-managed school program from São Gabriel da Cachoeira, Amazonas, adapting classes to work with indigenous values and cultural traditions for the mostly indigenous population $(90 \%$ of the municipality).

Reaproveitamento de Resíduos Orgânicos via Suinocultura: Organic waste recycling program in Porto Alegre, Rio Grande do Sul, through the production of pig feed, improving the environment and encouraging the pig farming industry.

Escola Família Agro-industrial de Turmalina: Rural school in Turmalina, Minas Gerais, where students alternate two weeks of full-time study boarding at the school, with two weeks in their own communities where lessons can be put into practice.

O Processo de Desenvolvimento Rural Sustentável em Urupema: Organization of civil society for participation in municipal budgeting and decision making to increase jobs and income on an environmentally sound basis in Urupema, Santa Catarina.

Projeto Microbacias Santa Catarina: State project from Santa Catarina for soil recuperation and conservation, controlling environmental pollution and improving agricultural production.

Consórcio Intermunicipal de Produção e Abastecimento: Consortium of fifteen municipalities in Maranhão, substituting imports and organizing a regional export economy to strengthen agricultural and livestock culture.
Segurança Pública, Direitos Humanos e Cidadania: Training program in human rights and citizenship fo police agents in Macapá, Amapá, with a view to a more humanitarian police force, better equipped to serve the general public.

Projeto Alerta: Program from Presidente Prudente, São Paulo, to help adolescents who have infringed the law find new paths to a future life project.

Programa de Modernização Administrativa: Administrative program from the Santo Andre government in São Paulo aiming at reforming the Municipal Administration's internal dynamics to better respond to local expectations.

Sobral Crianca: Program for the promotion of public policies which help construct and consolidate citizenship for children in Sobral, Ceará.

Fortalecimento Financeiro do Município com Justiça Fiscal a Servico da Cidadania: Implementation of financial and fiscal policy based on accounting transparency and civil participation in budgeting in Vitória da Conquista, Bahia.

Fundo Municipal de Aval: Financial loan program for productive sectors as part of the municipal plan for rural development in Poço Verde, Sergipe.

Centros de Atenção Psicossocial: Program from the city of Rio de Janeiro giving qualified assistance and attention to psychiatric care patients, seeking to maintain integration with families and communities and avoid periodic hospitalization.
Projeto Escola do Campo: Agricultural training program for school age youths in the rural communities of the state of Paraná.

Fique Vivo - Cidadania e Prevenção de AIDS com Jovens na FEBEM: AIDS prevention and civil rights program for youths aged 12 to 21 interned in the network of state youth shelters in São Paulo, working towards reinsertion and survival in society.

Política Pública Municipal de Abastecimento e Segurança Alimentar de Belo Horizonte: Administrative and financial structuring for the coordination and execution of the Municipal Policy for Food Provision and Safety in Belo Horizonte, Minas Gerais.

Projeto de Ação Integrada: Program in Teresina, Piauí, fighting for the eradication and prevention of child labor and exploitation in brick factories, recovering citizenship through insertion into schools, families and communities.

Bolsa Familiar para Educação - Bolsa-Escola: Aimed at youths aged 4 to 14 , in situations of extreme poverty, this program from Belém, Pará, seeks to boost school attendance by giving families a grant for children with a $90 \%$ attendance record.

Projeto Rede Autônoma de Saúde Indígena: Project for better living conditions of the indigenous population of São Gabriel da Cachoeira, Amazonas, by encouraging citizenship rights and more control in health issues for indigenous organizations.

Programa de Tratamento Participativo de Resíduos Sólidos da Região do Alto Rio Negro: Organization and structuring of actions for the treatment and disposal of solid waste in the Alto Rio Negro region of Santa Catarina. 